which had recelved injections of digitalis lived acreral hours or aven days longer timu either the control rabbits or those given aicurou. Definito quantities of the drags and of pueumococcus cultures were injected sccord. Ing to the weight of the anlmals. Jhoth aleuzon aod digltails, lisrmless In themseives to animais, produced a marked leucocytosis, hut they differed esscintiajiy in the fact that after the Injection of sleuron the hyperiencocytosis was qulckiy followed by a leukolysis and finally a lypoleucocytosis, whilio with digits lis the hyperleucocy tosis was sustalned for a compioratively long period. To these facts was sterihuted the favors bie action of digitalis and the failure of aleuron to proiong the lifo of the animais. $-W$. 'T. L.

\title{
HYGIENE AND PUBLIO HEALTH.
}

\author{
USORR TIE CHAROR OF \\ OHARI.SS IIARRINOTON, MY.D.,

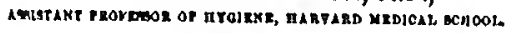

Is Typhold Fover sometimes Alr-borno?-In suppert of tho thicory that typhoid tevor may he air-borno, Quils (British Nedimal Sournal, Feb. ruary 15,1902$)$ glvon an account of tho clscumetnnces which olitalined in a inllitary camp in the hllls of Coylon, where latgo numbers of Joce prisoncte wero confinod. An epidenilo of typhoid forer doveloped, and no lees tian six lundred cases oceurcel. Tho water-aupply wns analyzed chemleally once a weck, and was oxamilned bactezlologleally wlth Irequeney. No freal, milk was allowed in camp. All carbonsted water used wns from the same source as thot sepplied to a noighiboring sanitarium, in which no typiboid fover occurred. No uncookod food of any deseription was used, and peeddlers of all kinds were riglily oxcluded from the camp. All perseris learlng tho grounds, for any pirpeso whatovor, nere requlred to earry wlth them a bottio of filtered wstor. Bince theso snitsry regulations were enforeed thoroughly, Quill belioves that the infection was air-horno from an adjoining camp of prisoners, where the discass provalied, ajthough tho possibility of transinission through tho agency of dies aftor visiting speciftcaliy infected istrines unust be borne in ninit.

Vauohan (Journal of the Amerimon Afedical Association, April Hi, 1002) aiso heiloves that dissomination of the typhoid fover baclilus in dust through the air lins heon clearly domenstrated, but ho hellores tint the most juportant incsns of dissemination of tho direasi ls apocifacsliy poiluted dirinkingwater, Frequently tho infectlyo agent lo erriled on tho bands and elothing of nurses and other attendante. It is his beliof that the disesso is norer spread by oxhaleal alr, although tho organlsm may oxlat in the sputun.

JEIIl, (Wiener linische Irochenvehrift, Fehruary 27, 1902) has found tho hacilius in tho sputum of cases of hronchitis with no lcajons of the intestlice, which suggests the possibllity of Inhavaitun with dust.

In the opinlon of Turner (British Medical Journal, Fehruary 15, 1902) It is a mistako to attach very great importanco to wird and files in tho 
eansation of epldemles of typhold fover. IIls experleneo of six years in Sonth Aeriea iras icd hin to bollovo that, in tho grent majority of cascs, tho eauso is to be found in a poiluted rrator-suppiy. IIo does not deny the passibility of alr-borno typhold, but points out tint lt dust Intection were n predominating or oven an Imporlant causo of typhoid fover, one would oxpeet to fnl tho dlsosso most provalent from shortly after tho beginulng of the dusty scason until shortly after lts elose; but tio notes, as a matter of fuct, that it is during this very period that typltold fover is icast prevalent. On the other thand, tt ts durtug the wet senson, when, on necount of heavy rain, there ls no dnst, that tho disense is most prevalent. Although conceding tho possibility of tho transmission of typhold fever by fles, he pointe out that, in Sonth Afriea, flies begtn to bo troublesomo long before typhotd tever provaita, and continuo to be so long after its subsideneo. In answer to the ecttieism that typhold fover provatled among the British troops In splte of the fact that fiters wero provtded, ho anacrls, of hls own kuowieigo, that the fiters were not gencraily uted, and that where the commanding oflecr of a regiment onforced tho use of filtera the number of cases in that particular body was insigniflent.

Boubora (Zeitechrift fur Irygiene und Infectionalrankhrilen, IBand xxxvili., p. 343) has collectel roperts of 650 opidemics of typituld fever in all parts of the world, of which 377 occurred in Germany, 140 in England, and 66 in Frnnce. It nppears that 70.8 por cont. of these were due to contamiluatel water, 17 per cent. to eontaminnted milk, and 3.5 per ecnt. to other fools. In rcality, wates na a causo propondernted even inoco than is bece shown, since oven aminng those attributed to milk and other foods, as oyaters, etc., it la probable that lu some instances a polluted water may have bcen a contributing if not the main cateo. Spenklng alse of the teensaission of the disense froun porson to persoll, ho takes as $n$ orcasuro of tho dangor tho reia. thon between the whole iumber of eases in cer talu hospitelo and elinles nud tho number of casce occurelng nmong the nursing siaft and among other pationts. Of 35,617 crses of tho disense, 1179-that is to say, 3.3 per ecut. -occurcel nnong the tursing stnit and other patienta; of 23,554 cases in the l'russian nititary itospltnis during the perlod $1881-1897,1012$, or 4.3 jer cent., were nmong the personnol of the hospitnl; anl $478-$ that is to say, 2 per eent.-anong patlents who were present on aecount of other siekness. Tho vehilele of tofeetlon is chichy tho diseharges, and particutarty the urine, of those slek and convaluseont. Ilo recommends tho protection of the nursing body by antityphoil lnoeulatlons, aceordlng to the metheil of Maradou nnd Wright.

Pregervation of Meat by Means of Borax.-Vavonan and Versirosls (American Sedicine, Mareb 15, 1902, p. 42t), oxpertmenttug with borax on ineat, fonnd that meat not treated with borax, and kept at ordinary temperatures, becomes silmy within a fow days. Frotn the surfaces of speciwens no kept thoy isoloted twenty different speeies of micro-orgnnisms, fourteen of whieh wero peptonlzing baeterla. Inasmueh as it is tho ustitl practico to wash moats so trcated as soon gas they arrive at their deatinetion, they seo no objection to thls uso of borax; and lt would appeac reasonabic nnil proper to ailow the practiee, provlded the preservatives do not pene- 